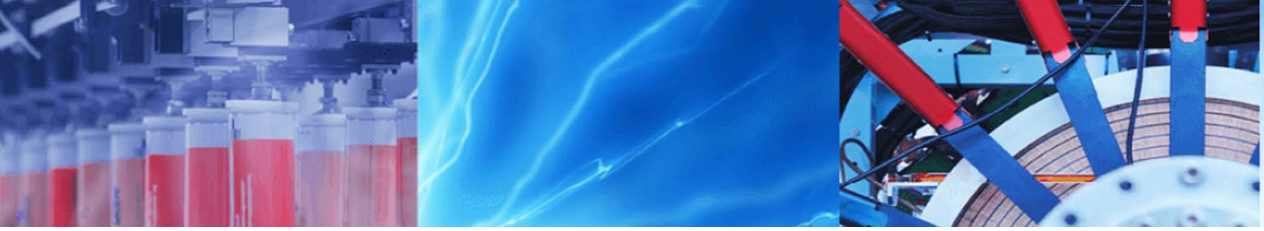

\title{
Review Paper
}

\section{Temperature dependence of CIGS and perovskite solar cell performance: an overview}

\author{
Leqi $\operatorname{Lin}^{1}\left[\right.$ (D) N. M. Ravindra ${ }^{2}$ (I)
}

Received: 12 March 2020 / Accepted: 2 July 2020 / Published online: 10 July 2020

(c) Springer Nature Switzerland AG 2020

\begin{abstract}
CIGS, with a tailorable direct band gap (of 1.04-1.68 eV), can serve as bottom cell with excellent band gap match with perovskite (1.6-2.3 eV) in the combined monolithic perovskite/CIGS tandem solar cell, that has the potential to exceed the Shockley-Queisser limit. Thus, an investigation of the operating temperature dependence of the performance of CIGS and perovskite solar cells (PSCs), in the temperature range of $80-380 \mathrm{~K}$, based on studies in the literature, is presented. Besides the operating temperature, the influence of substrate temperature of CIGS solar cells, fabricated on soda-limeglass, polyimide foil and stainless steel substrates are also investigated. The solar cell performance is assessed by considering several photovoltaic parameters such as short circuit current density $\left(U_{s c}\right)$, open circuit voltage $\left(V_{o c}\right)$, fill factor and power conversion efficiency. By a detailed understanding of the dependence of solar cell parameters on temperature for CIGS solar cells and PSCs, with different characteristics or structures, it is anticipated that an effective pathway for the improvement in these cells, in adverse environments, can be accomplished.
\end{abstract}

Keywords Solar cells · CIGS · Perovskite solar cells · Temperature dependence

\section{Introduction}

Today, from the perspective of photovoltaics, perovskites represent one of the most successful optoelectronic candidates with significant growth in their performance since 2009; they play a critical role in the next-generation solar cells for both terrestrial and space applications. Further, CIGS holds a market share of $21 \%$ of the total global thin film production among two other major materials, $\mathrm{CdTe}$ (76\%) and a-Si (3\%) according to the Photovoltaic Report by Fraunhofer Institute for Solar Energy Systems, ISE [1] (based on CIGS, CdTe and a-Si as the principal thin-film solar cell materials). Thin film solar cells [2] continue to enhance their role as high efficiency, reliable and costeffective alternative to conventional mono-crystalline silicon solar cells due to their lower material costs, rising efficiencies and ease of fabrication. Furthermore, thin-film solar cells have significant potential and critical advantages in sunbelt countries with better temperature coefficients and ideal power conversion efficiencies (PCE) in adverse environments over crystalline silicon solar cells [3]. The fundamental equations governing the performance of solar cells have been described in a large number of studies in the literature. In a previous study, Singh and Ravindra [4] have investigated the temperature dependence of $\mathrm{Si}$, $\mathrm{Ge}, \mathrm{GaAs}$, InP, CdTe and CdS solar cells. The first studies of the comparison of solar cell efficiency versus $E_{\mathrm{g}}$ for various semiconductors, in the temperature range of 273-673 K, by Wysocki and Rappaport, were reported 60 years ago [5]. It is interesting and relevant to note that while there have been significant improvements in solar cell materials and device technology, not much has changed relative to the

$\triangle$ N. M. Ravindra, n.m.ravindra@njit.edu; nmravindra@gmail.com | ${ }^{1}$ Department of Civil and Environmental Engineering, New Jersey Institute of Technology, Newark, NJ, USA. ${ }^{2}$ Interdisciplinary Program in Materials Science and Engineering, New Jersey Institute of Technology, Newark, NJ, USA. 
absolute solar cell efficiencies as function of materials and temperature. The temperature dependence of the bandgap $\left(E_{\mathrm{g}}\right)$ of semiconductors is described by the well-known Varshni relation [6] in Eq. (1), where $E_{g}(T)$ is the bandgap of the semiconductor at temperature $T, E_{g}(0)$ is its value at $0 \mathrm{~K}$, and $\alpha$ and $\beta$ are constants that are material dependent.

$E_{g}(T)=E_{g}(0)-\frac{\alpha T^{2}}{(T+\beta)}$

Since the first report of CIGS solar cells by Devaney and Mickelsen in 1987 [7], the technology has grown over the years; the best record efficiency of CIGS solar cells of $22.9 \%$ has been reported by Solar Frontier on glass substrates [8]. Normally, the structure of CIGS solar cell starts with soda-lime glass(SLG) substrate and Mo back contact on the bottom, followed by CIGS as the interlayer, on the top are $\mathrm{ZnO} / \mathrm{Al}: \mathrm{ZnO}$ and n-type $\mathrm{CdS}$ as window layer, and it is usually fabricated by a co-evaporation process and precursor reaction process. The cross section of a typical CIGS solar cell is as shown in Fig. 1a. The emerging thin film material solar cells, perovskite solar cells (PSCs), have also attracted increasing scientific and technological interest because of their high efficiency that can be attributed to their ability to fulfill the multiple roles of light-absorption, charge separation, transportation of holes and electrons in materials [9]; additionally, they offer the benefit of the use of low amounts of earth abundant materials. PSCs, based on either mesoscopic or planar, normal (n-i-p) or inverted $(p-i-n)$ structure architectures, are typically described by the formula $A B X_{3}$, where $X$ is a halide anion, $A$ is an organic

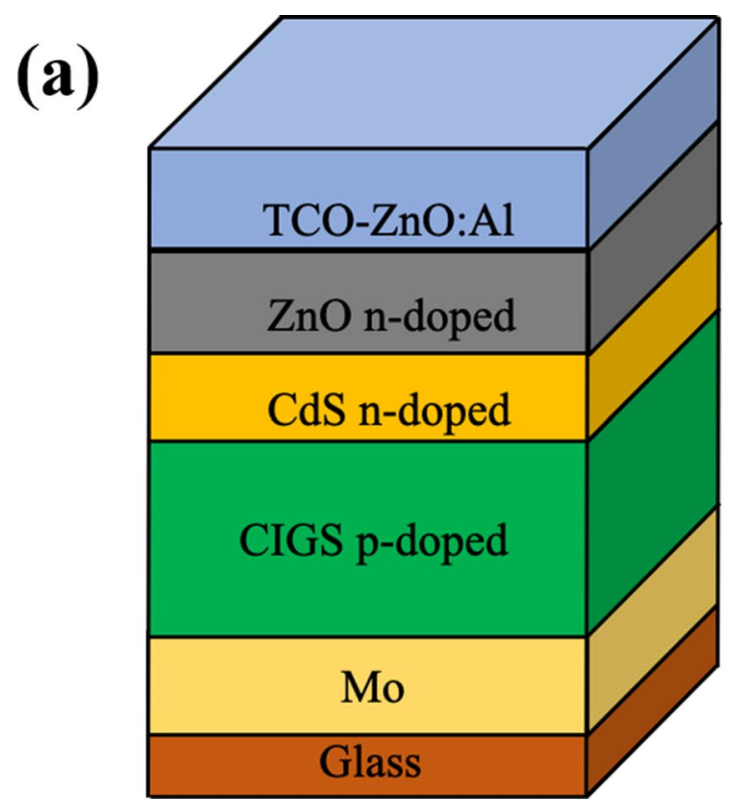

Fig. 1 Cross section of $\mathbf{a}$ a typical CIGS solar cell, $\mathbf{b}$ perovskite solar cell and/or inorganic cation, such as MA (methylammonium cation $\left(\mathrm{CH}_{3} \mathrm{NH}_{3}^{+}\right)$), $\mathrm{FA}$ (formamidinium $\left(\mathrm{CH}(\mathrm{NH} 2) 2^{+}\right)$), $\mathrm{Cs}$ and $\mathrm{Rb}$ and $\mathrm{B}$ is metal cation such as $\mathrm{Pb}$ (A being larger than $B$ ). The cross section of a typical perovskite solar cell is as shown in Fig. 1b [10]. Since the first report of PSCs with $3.8 \%$ power conversion efficiency (PCE) by Kojima et al. in 2009 [11], the organometal halide PSCs have been demonstrated with high PCE of $>23 \%$ on a lab-scale [12]. Enhanced light harvesting by using two or more absorbers, with different band gaps, has so far been the most effective approach to increase the PCE from 20 to over $30 \%$ beyond the practical limits of single $p-n$ junctions. Conventionally, the low PCE of tandem device is primarily limited by the low efficiency and non-ideal bandgap of the top structure of the cells. This situation has changed with the advent of perovskite solar cells with wide and tunable band gap over a broad energy range [13]. Perovskite materials are, in most cases, direct-bandgap semiconductors with a bandgap ranging across the entire visible spectrum [14]. Among various kinds of tandem cells, perovskite/CIGS thin-film tandem cells hold great promise as each single junction cell has attained $>23 \%$ efficiency [15] and the bandgaps of both absorbers can be easily tailored for current matching conditions [16].

The study of the behavior of solar cells with temperature $(T)$ is important as, in the working condition, they are generally exposed to temperatures ranging from 288 to $323 \mathrm{~K}$ [17] and to even higher temperatures in space and concentrator systems (370-380 K) [18]. The performance of solar cells is determined by the photovoltaic (PV) parameters, for example, short circuit current density $\left(J_{\text {sc }}\right)$, open

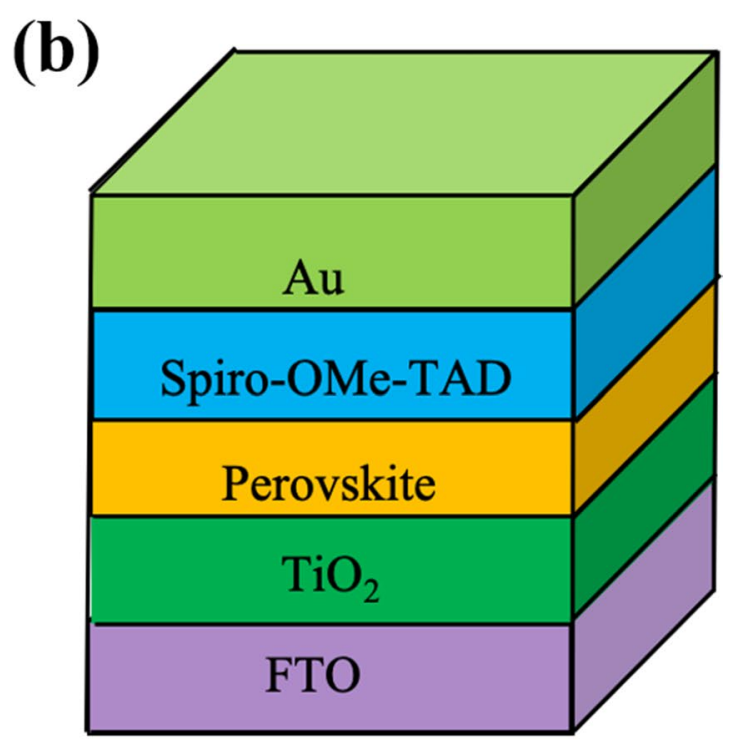


circuit voltage $\left(V_{\mathrm{oc}}\right)$, fill factor (FF) and PCE. These parameters are temperature-dependent and hence affect the performance of solar cells [4]. In general, $V_{\text {oc }}$ decreases with increasing temperature and $J_{s c}$ increases slightly with increasing temperature [4]. Both FF and PCE decrease with increasing temperature and PCE degradation is mainly due to the decrease in $V_{\text {oc }}$ [4]. The temperature-related studies will be important for further improvement in performance of these PV cells. In the first section, this paper presents a review of the dependence of PV parameters of CIGS solar cells on operating temperatures and substrate temperatures $\left(T_{\text {sub }}\right)$. The substrate has a crucial role in determining the PCE performance of the whole device. The operating temperature dependence of PV parameters of PSCs based on different perovskite materials, $\mathrm{MAPbl}_{3}, \mathrm{FAPbl}_{3}$, $\mathrm{MAFAPbl}_{3}$ and $\mathrm{CsMAFAPbl}$, are discussed in the second section.

Besides, CIGS, with a tailorable direct band gap (of 1.04-1.68 eV), can serve as bottom cell with excellent band gap match with perovskites (1.6-2.3 eV) [19] in the combined monolithic perovskite/CIGS tandem solar cell. This flexible tandem solar cell device promises high PCE that exceeds the Shockley-Queisser limit, enabling costefficient and ultra-lightweight cells for applications in terrestrial and space photovoltaics with power-to-weight and power-to-cost ratios surpassing individual cells and those of III-V semiconductor-based multijunctions [20]. Thus, it is important to realize the compositional and thermal stability among different substrates and perovskite materials. Furthermore, the degradation behavior of PV parameters with thermal stability is studied in detail for commercially available perovskite and CIGS solar cells. Such studies will help to investigate the degradation processes that have been mainly responsible for reduction in PV parameter performance. Here, we investigate the performance characteristics as function of temperatures, higher or lower than STC, for the understanding and prediction of solar cell performance in real-world working conditions, from applications point of view as well as in manufacturing.

\section{CIGS solar cells: photovoltaic parameters as a function of substrate material and influence of substrate temperature}

CIGS solar cells have demonstrated good performance for most of the visible spectrum under terrestrial conditions at high operating temperature $(350 \mathrm{~K})$; besides, they can also be used for space applications due to their high radiation tolerance [21]. Generally, for most semiconductors, $E_{\mathrm{g}}$ decreases with increase in temperature. Therefore, increasing temperature contributes to the increase in $J_{s c}$ and decrease in $V_{\text {oc }}$, besides, the increasing temperature, in general, increases the probabilities of recombination which eventually leads to the reduction in PCE [22]. The temperature dependence of efficiency of CIGS solar cells is of great relevance, such as for space applications in which panels are subjected to temperatures varying from 80 to $380 \mathrm{~K}$ within a few minutes after eclipse [18] and also for terrestrial applications where they could be subjected to environmental temperatures as high as $350 \mathrm{~K}$. The PV parameters of CIGS solar cells on three different types of substrates, SLG (Sodium Lime Glass), SS (Stainless Steel foils) and PI (Polyimide), are studied in order to assess the influence of the substrate on the internal operation of the cell.

\subsection{Effect of different substrates on photovoltaic parameters}

The substrates in CIGS solar cells have a crucial role in the development of the whole device. Deposition of the Mo back contact on SLG or flexible substrate will define different selenization conditions [23]. Conventionally, most commercial CIGS solar cells are produced on SLG substrates since SLG provides a sufficient source of $\mathrm{Na}$ (alkali metal) to the absorber naturally [24] and is able to sustain high temperature during deposition and annealing processes. In recent years, CIGS solar cells deposited on light weight and flexible substrates have been studied for versatile applications [25]; for example, flexible CIGS solar cells can be integrated on rooftops or as a bending module with curved surface. So far, efficiencies of $22.8 \%$ on SLG substrate [8], $17.5 \%$ on SS substrate [26] and $20.4 \%$ PI substrate [27] for CIGS solar cells have been achieved. Among various SS substrates, stainless $\mathrm{Cr}$ steel is expensive but with lower coefficient of thermal expansion, and unalloyed Fe steel is cheaper but with the corrosion issue and higher coefficient of thermal expansion $\left(13 \mathrm{ppm} \mathrm{K}^{-1}\right.$ for $\mathrm{Cr}$-free steel compared to $11 \mathrm{ppm} \mathrm{K}^{-1}$ for $\mathrm{Cr}$ steel at $823 \mathrm{~K}$ ) [28]. Besides SS substrates, $\mathrm{PI}$ substrate is an attractive choice due to its vacuum and temperature stability and is considered as a good candidate for alkali doping technology; it can be readily accomplished due to the fact that only a small amount of impurities diffuse out of the PI substrate [29].

In Fig. 2, the data on the $V_{\text {oc }}-T$ relationship of GIGS solar cells on SS, PI and SLG substrates, from the recent 10 years of literature, are summarized. The results show a consistent and negatively linear behavior with high correlation factor $\left(R^{2}>0.998\right)$, for a variety of substrates, which eventually can be attributed to a reduction in the PCE for the temperature range of 100-360 K. Besides, $V_{\text {oc }}$ on SLG substrate has continuously higher value than alkali-doped PI substrate and SS substrate, which may be due to the presence of lower concentration of 


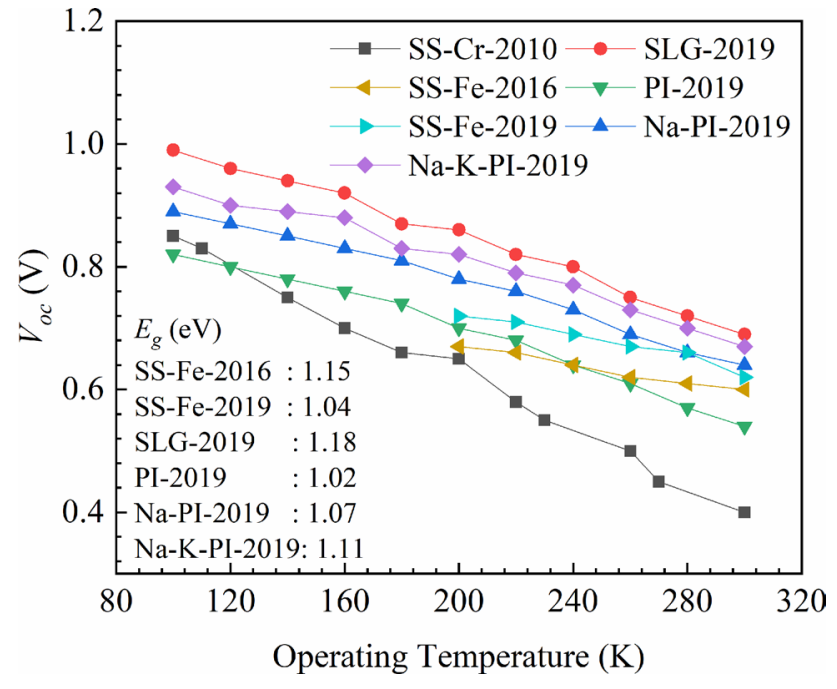

Fig. $2 V_{\text {oc }}-T$ plot for different substrates. The data in the figure are extracted from Refs. [29-32]

defects or better absorber quality on SLG substrate. CIGS solar cells on alkali-doped PI substrates, Na-PI-2019 and $\mathrm{Na}-\mathrm{K}-\mathrm{PI}-2019$, performed better than undoped PI and SS substrates. Especially, the performance of CIGS solar cells on Na-K-PI-2019 is very close to that of CIGS solar cells on SLG-2019; the difference in $V_{\text {oc }}$ values may be attributed to the differences within CIGS and may not be due to the substrate. This confirms that in addition to $\mathrm{Na}$ content, the incorporation of $\mathrm{K}$ from the substrate into CIGS helps to passivate the defects via inter-diffusion of In and $\mathrm{Ga}$ atoms and suppress the recombination process in the CIGS absorber [29]. The diffusion of the detrimental impurities (e.g., Fe) increases with increasing temperature and is a major challenge for high-efficiency CIGS modules on SS substrates, in which barrier layers are normally used to prevent this impurity diffusion $[33,34]$. $E_{\mathrm{g}}$ of CIGS can be varied from 1.04 to $1.68 \mathrm{eV}$ by varying the composition within CIGS to absorb most of the photons. In Fig. 2, we also notice that the change in $V_{\text {oc }}$ as function of $V_{\text {oc }}-T$, is almost uniform and is generally independent of $E_{\mathrm{g}}$. Further, in Fig. 2, the CIGS films on similar SS-Fe substrates (SS-Fe-2016, $E_{\mathrm{g}}=1.15$ [35]; SS-Fe-2019, $E_{\mathrm{g}}=1.04$ [36]) showed that the CIGS films with higher $E_{\mathrm{g}}$ exhibited better thermal stability than CIGS films with lower $E_{\mathrm{g}}$. This is the same case with CIGS films on PI substrates with and without alkaline doping to advance the material properties and $E_{\mathrm{g}}$.

From two simulation studies, shown in Fig. 3 , it can be noted that $J_{\mathrm{sc}}$ decreases slightly with increasing temperature in the temperature range of $260-370 \mathrm{~K}$. This slight decrease in $J_{\mathrm{sc}}$ is ascribed to reflection losses (series and shunt resistance) and recombination losses, as described by Eq. (2). [4]. However, CIGS on PI substrate showed a
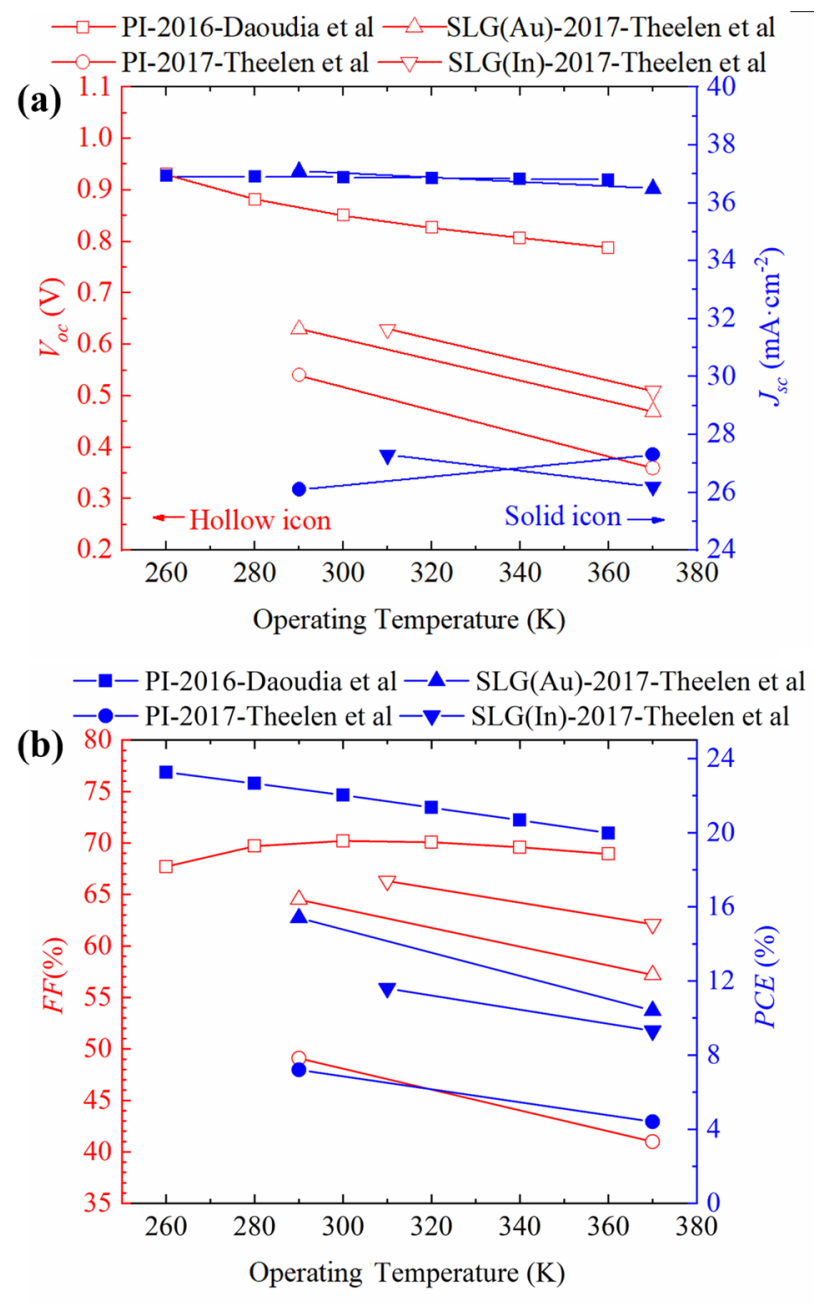

Fig. 3 Temperature dependence of PV parameters (e.g., PCE, FF, $V_{o c}$ and $J_{\text {sc }}$ ). The structure of CIGS solar cell [2016-Daoudia et al.-PI] is $\mathrm{PI} / \mathrm{Mo} / \mathrm{CIGS} / \mathrm{CdS} / \mathrm{i}-\mathrm{ZnO} / \mathrm{ZnO}$ :B; for (2017-Theelen et al.-PI) is $\mathrm{PI} / \mathrm{Mo} /$ CIGS/CdS/i-ZnO/ZnO:Al; for (2017-Theelen et al.- (SLG(Au)) is SLG/ $\mathrm{Mo} / \mathrm{CIGS} / \mathrm{CdS} / \mathrm{i}-\mathrm{ZnO} / \mathrm{ZnO}: \mathrm{Al} / \mathrm{Au})$. The data in figure are extracted and regenerated from Refs. [37, 38]

slightly positive temperature dependence on $J_{s c^{\prime}}$ which is different from the others.

$J_{s c}=q \int_{h v=E_{g}}^{\infty} \frac{\mathrm{d} N_{p h}}{\mathrm{~d} h v} \mathrm{~d}(h v)$

As a consequence, most of the PV parameters (e.g., FF, $V_{\mathrm{oc}}$ and $J_{\mathrm{sc}}$ ) have similar trends in temperature dependency on different substrates, mostly, a negative trend. In accordance with Eqs. (3)-(5), we can conclude that PCE decreases with increasing temperature as temperature has a positive impact on the intrinsic carrier concentration $\left(n_{i}\right) . J_{o}$ increases with increasing $n_{i}$ which further decreases the $V_{\text {oc }}$. The steady loss of $J_{\text {sc }}$ on SLG substrate 
or slight increase on PI substrate, in which the $J_{\text {sc }}$ is not enough to compensate for the loss of $V_{\text {oc }}$ eventually lead to decreased FF and PCE with increasing temperature. $J_{O^{\prime}}$ saturation current density, is proportional to the square of the intrinsic carrier concentration for a solar cell which has been modeled [39] as in Eq. (3).

$J_{\mathrm{o}}=q \times B \times\left(\frac{D_{n}}{L_{\mathrm{n}} N_{\mathrm{A}}}+\frac{D_{\mathrm{p}}}{L_{\mathrm{p}} N_{\mathrm{D}}}\right) n_{i}^{2}$

where $q$ is the electronic charge, $n_{i}$ is the intrinsic carrier density, $B$ is another constant independent of temperature, $N_{A}$ and $N_{D}$ are densities of acceptor and donor atoms, $D_{\mathrm{n}}$ and $D_{\mathrm{p}}$ are diffusion constants of minority carriers in $\mathrm{p}$ and $\mathrm{n}$ regions, and $L_{\mathrm{n}}$ and $L_{\mathrm{p}}$ are length of minority carriers in $p$ and $n$ regions, respectively. As seen from Eq. (3), $J_{0}$ is strongly determined by the proportionality to $\sim n_{i}^{2}$ and $n_{i}$ can be represented as in Eq. (4).

$n_{i}^{2}=A \times T^{3} \times \exp \left(-\frac{E_{g}}{k T}\right)$

By combining Eqs. (3) and (4), in the presumption of temperature dependence of all parameters except $n_{i}$, the expression for $J_{0}$ can be written in terms of temperature and bandgap energy [40] as in Eq. (5), where $C$ is the third constant independent of temperature.

$J_{\mathrm{o}}=C \times T^{3} \times \exp \left(-\frac{E_{\mathrm{g}}}{k T}\right)$

Moreover, a deduction is made that SS substrate should hold the same temperature dependency on PV parameters as PI and SLG. Besides, it should be noted that the obvious difference in the values between the same substrates from two literatures may be due to the large variation between individual CIGS solar cells. But the temperature dependence of PV parameters of CIGS, when deposited on different substrates (e.g., SLG, SS and PI), has mostly the same relationship.

\subsection{Effect of substrate temperature on electrical properties}

High substrate temperature will not only enhance the growth of the absorber layer but also favor alkali-diffusion from substrate to absorbers. Most of the high-efficiency CIGS modules have been prepared at substrate temperature $\left(T_{\text {sub }}\right)$ of over $773 \mathrm{~K}$ which is very close to the softening temperature of SLG substrates [41]. Low substrate temperature $(<723 \mathrm{~K})$ provides the feasibility for reducing the thermally induced stress on the substrate, for example, by depositing Mo on PI [42]. PI substrate is suitable for continuous and rapid roll-to-roll deposition process and hence reduces the manufacturing cost of CIGS solar cell module [43]. The use of PI substrate reduces the $T_{\text {sub }}$ and can lead to a decrease in manufacturing costs. The use of high substrate temperature with glass substrates promises enough thermal energy to form high-quality CIGS films. $T_{\text {sub }}$ also plays an important role in providing the thermal energy for the inter-diffusion between atoms, which is also related to the phase transformations in the growth process of CIGS. Here, we investigate the effect of $T_{\text {sub }}$ on the structural and electrical properties of CIGS films on various substrates.

In the case CIGS/SLG, with $T_{\text {sub }}$ in the temperature range of 623-773 K, by using one-stage co-evaporation process [44], the enhancement in PCE, FF and $V_{\text {oc }}$ is observed when $T_{\text {sub }}$ is increased from 573 to $773 \mathrm{~K}$. Especially, a significant increase, above a critical temperature of $723 \mathrm{~K}$, is observed due to the drastic increase in carrier concentration. This is because of the diffusion of Na content from SLG into the CIGS absorber at temperatures above $723 \mathrm{~K}$, which also decreases the resistivity. The FF and $V_{\text {oc }}$ have similar increasing trends as PCE which may be ascribed to the improvement in $\mathrm{Na}$ diffusion at higher temperature on SLG substrates [45]. Additionally, the decrease in $V_{\text {oc }}$ with decreasing $T_{\text {sub }}$ can be explained by recombination occurring in the grain boundary due to the smaller grain size at low temperature [46]. Low $J_{s c}$ values at lower temperature $(<673 \mathrm{~K})$ can be attributed to the poor quality of CIGS films which reduces the carrier collection. It is worthwhile to note that many papers in the literature have reported slight decrease in $J_{\mathrm{sc}}$ after the substrate temperature reaches $\sim 823 \mathrm{~K}$, which is in contrast to other parameters such as FF, $V_{\text {oc }}$ and PCE $[44,47]$. Similar results of PV parameters with $T_{\text {sub }}$ can be observed in the literature $[44,47$, 48], for the case of CIGS cells/SLG substrates which have the same structure of glass/Mo/CIGS/CdS/i-ZnO/AI-ZnO. It is commonly expected that, with increase in $T_{\text {sub }}$ (over $800 \mathrm{~K}$ ), the enhancement of larger grain growth occurs. Eventually, they form big blocks of grains when $T_{\text {sub }}$ is in the temperature range of $823-873 \mathrm{~K}$, which shows that high $T_{\text {sub }}$ can give enough thermal energy to form highquality CIGS films. The high PCE at $T_{\text {sub }}$ of $823 \mathrm{~K}$ is related to $\mathrm{Na}$ incorporation and the disappearance of secondaryphase $\left(\mathrm{In}_{0.62} \mathrm{Ga}_{0.38}\right)_{2} \mathrm{Se}_{3}$, which helps to process films with better structural properties.

In 2016, Liang et al. [31] studied the influence of $T_{\text {sub }}$ on CIGS module (SS/Mo/CIGS/CdS/i-ZnO/n-ITO/AI) with the cells deposited on SS substrate using a 3-stage co-evaporation process. In this case, $V_{\text {oc }}$ increases with increasing substrate temperature but reaches a slow trend for $T_{\text {sub }}$ above $783 \mathrm{~K}$. This may be due to a wider $E_{\mathrm{g}}$ that can be achieved with a higher $T_{\text {sub, }}$ which can effectively decrease the saturation current and therefore increase the $V_{\text {oc }}[49]$. The comparison of $V_{\text {oc }}-T$ and $J_{\text {sc }}-T$ behavior of Liang's study on SS substrate with other studies in the literature 
on different substrates (e.g., SLG and PI) is presented in Fig. 4a. It may be noted that $J_{\mathrm{sc}}$ initially increases and then decreases with temperature $>773 \mathrm{~K}$, which is also observed in the $J_{\text {sc }}-T$ relationship on SLG substrate. Here, the author suggests that the decrease in $J_{\mathrm{sc}}$ as the substrate temperature $\sim 773 \mathrm{~K}$ may be ascribed to the increasing Fe concentration, which could replace In and Ga lattice sites and enhance the recombination probabilities [28]. The comparison of FF- $T$ and PCE- $T$ behavior between Liang's study on SS substrate and other studies in the literature on different substrate (e.g., SLG and PI) can be seen in Fig. 4b. In addition, low FF values for lower substrate temperature $(<723 \mathrm{~K})$ for both SS and SLG substrates can be ascribed to the larger grain boundaries. However, for high substrate temperature, close enough to material
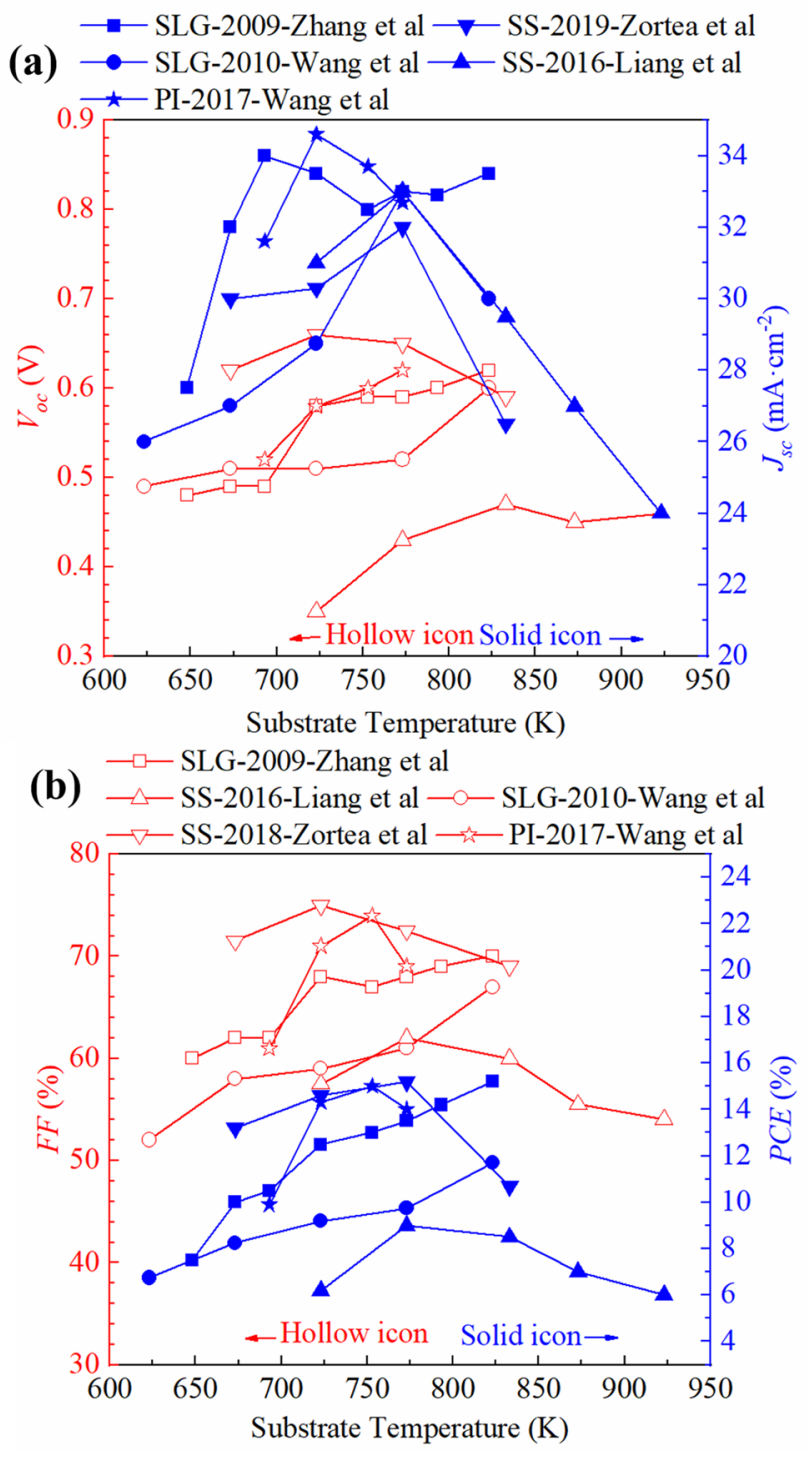

Fig. $4 \mathrm{~J}-V$ parameters of CIGS solar cells on different substrates at different $T_{\text {sub }}$. Data extracted from Ref. [31, 32, 44, 45, 50] softening temperature (in the case of SS substrate, it is $\sim 773 \mathrm{~K}$ ), impurities of high concentration may diffuse into CIGS modules and act as shunt path [33]. The same relationship between PV parameters and $T_{\text {sub }}$ is observed in the literature, for example, Zortea et al. [32] on unalloyed SS substrate by using a 3-stage co-evaporation process. In recent years, the use of SS substrate has caught researchers' interests due to a better substrate temperature dependence of PV parameters with polished surfaces (low irregularities), which could possibly reduce pin holes and shunts during subsequent processing [30]. In the study reported by Zortea et al. [32], impurity concentration increases with increasing substrate temperature which causes defect states and leads to additional recombination losses, as shown in Fig. 5. This eventually leads

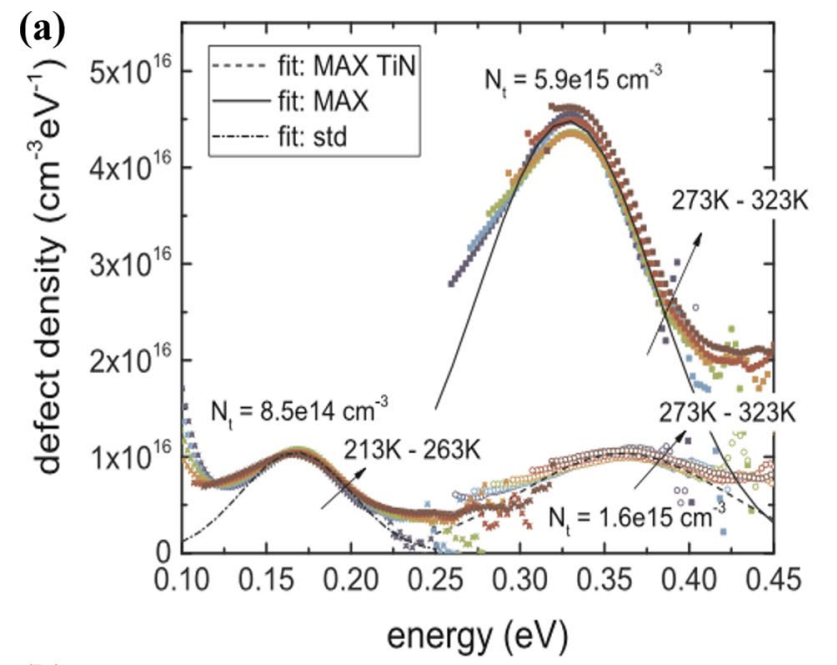

(b)

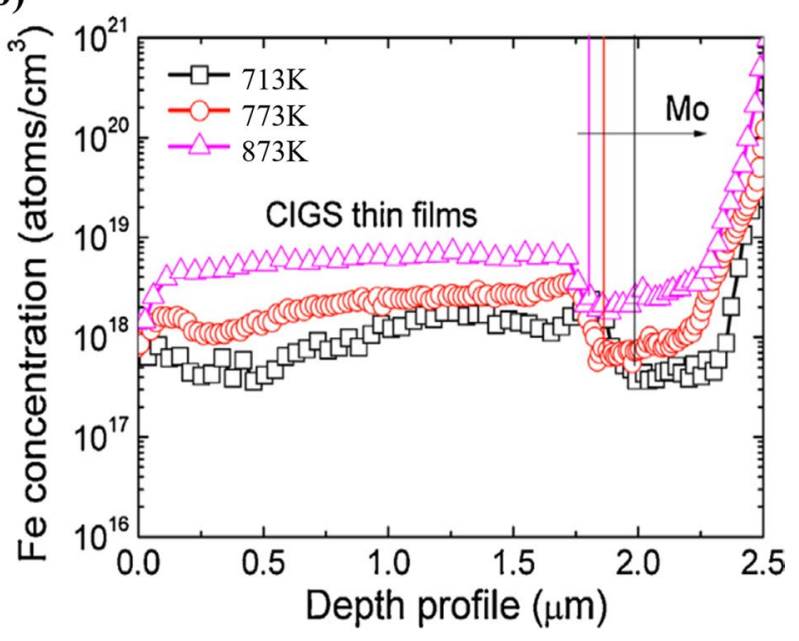

Fig. 5 a Calculated defect spectra of solar cell on SS substrate of MAX ( $T_{\text {sub }}$ of $\left.833 \mathrm{~K}\right)$, std ( $T_{\text {sub }}$ of $723 \mathrm{~K}$ ) and Max TiN (SS substrate with TiN barrier layer at $T_{\text {sub }}$ of $833 \mathrm{~K}$ ) b Fe content profiles in CIGS solar cell on SS substrate for $T_{\text {sub }}$ of $713 \mathrm{~K}, 773$ and $873 \mathrm{~K}$ by SIMS measurements. Reprinted and reproduced with permission from Ref. [31] and Ref. [32], respectively 
to a decrease in efficiency for high $T_{\text {sub }}(>773 \mathrm{~K})$. Thus, a more precise control of the processing temperature would facilitate in designing a distinct $T_{\text {sub }}$ profile for growing $\mathrm{CIGS}$ on SS substrates. The diffusion barrier layer between the substrate and the Mo back contact is also helpful to suppress the diffusion of detrimental elements from the substrate into the CIGS when $T_{\text {sub }}$ is $<773 \mathrm{~K}$.

It is well known that CIGS absorbers in high-efficiency cells are normally deposited at high $T_{\text {sub }}(>823 \mathrm{~K}$ ) on rigid SLG substrates. However, for temperature sensitive flexible PI substrates, its thermal stability limits the process temperatures to about $723 \mathrm{~K}$, which is $100 \mathrm{~K}$ less than SLG; thus, a low substrate temperature deposition technique is necessary while deploying flexible substrates. Zhang et al. [50] investigated the PV properties of CIGS solar cell (Mo/CIGS/CdS/i-ZnO/n-ZnO:Al/Al grid) on SLG and PI substrate in the temperature range of $673-773 \mathrm{~K}$, by using a 3-stage co-evaporation process. The results show that $V_{\text {oc }}$ increases with increasing substrate temperature $\left(T_{\text {sub }}\right.$ in the range of $673-753 \mathrm{~K}$ ) and decreases for $T_{\text {sub }}>753 \mathrm{~K}$. $\mathrm{FF}$ of CIGS cells on PI substrate increases with increasing $T_{\text {sub }}$; the lower FF of CIGS cells on PI substrates than those on SLG may be ascribed to the large grain boundaries [51] and the shunt resistance caused by the relatively rough surface of PI substrate. This reasoning is also consistent with studies of CIGS cells on SS substrate as reported by Zortea et al. [32]. It should be noted that the CIGS solar cell on PI substrate exhibits higher $J_{\text {sc }}$ values due to the higher spectral response in the long wavelength range of 550-1100 nm [50]. $T_{\text {sub }}$ has a stronger influence on PI with respect to the thermal absorption and emission properties when compared with SLG [50]. Accordingly, the CIGS absorber with relatively low defects, formed on $\mathrm{PI}$, leads to a relatively long carrier lifetime and a reduction in recombination probabilities.

\section{Perovskite solar cell photovoltaic parameters as function of material properties and influence of temperature}

Hybrid organometal halide perovskite materials, such as $\mathrm{MAPbl}{ }_{3}, \mathrm{FAPbl}_{3}$ and $\mathrm{MA}_{x} \mathrm{FA}_{(1-x)} \mathrm{Pbl}_{3}$ have been investigated widely for light harvesting in PSCs. In most recent studies, PSCs based on: (a). MAPbl ${ }_{3}$ have achieved $21 \%$ PCE [35]; (b). $\mathrm{FAPbl}_{3}$ have achieved 21.07\% PCE [36] and (c). $\mathrm{MA}_{x} \mathrm{FA}_{(1-x)} \mathrm{Pbl}_{3}$ have achieved $21.6 \%$ PCE $[52,53]$. Inorganic $C s$ ion has been used to enhance the thermal stability of perovskite cation combinations (e.g., Cs/MA, Cs/ $\mathrm{FA}$, and $\mathrm{Cs} / \mathrm{MA} / \mathrm{FA}$ ); this has resulted in cells with $20.32 \%$ PCE. [54, 55] Commonly, PCE is measured in the laboratory under standard test conditions (STCs, $25^{\circ} \mathrm{C}$ and AM1.5G with $100 \mathrm{mWcm}^{-2}$ ). However, solar cells in the working condition will operate at lower and higher temperatures, leading to changes (and often a decrease) in the average PCE, as reported for silicon solar cells [56]. Apart from the importance of material characteristics affecting the performance of PSCs, temperature-dependent photovoltaic behavior of PSCs is also highly desirable to study. $\mathrm{Cs}_{0.05}\left(\mathrm{MA}_{0.17} \mathrm{FA}_{0.83}\right)_{0.95} \mathrm{~Pb}\left(\mathrm{I}_{0.83} \mathrm{Br}_{0.17}\right)_{3}$, with $E_{\mathrm{g}}=1.62 \mathrm{eV}$ [20], has been investigated and has been shown to exhibit high thermal stability for applications in PSCs.

\subsection{Hybrid organometal halide perovskites: MAPbl- $_{3}$, FAPbl- $_{3}$, MAFAPbl- $_{3}$ and CsMAFAPbl ${ }_{3}$-based solar cells}

As stated by Shockley and Queisser, in general, the $E_{\mathrm{g}}$ of the semiconductor affects the performance of the cell [57]. Seok et al. showed that the $E_{\mathrm{g}}$ of perovskites can be changed by altering the length of lead and halide site, by either changing the halide, the metal or the ion size [58]. Particularly, the $E_{\mathrm{g}}$ of the perovskite decreases when changing the cation from MA to larger FA cation [59]. In this work, an analysis of the PV parameters of PSCs, at operating temperatures in the range of $80-360 \mathrm{~K}$, based on different perovskite materials, such as $\mathrm{MAPbl}_{3}\left(\mathrm{CH}_{3} \mathrm{NH}_{3} \mathrm{Pbl}_{3}\right)$, $\mathrm{FAPbl}_{3}\left(\mathrm{NH}_{2} \mathrm{CHNH}_{2}\right), \mathrm{MA}_{\mathrm{x}} \mathrm{FA}_{(1-x)} \mathrm{Pbl}_{3}$ and CsMAFAPbl 3 , is presented. The temperature activated formation and migration of ionic defects within the perovskite lattice remains a potential source of instability for perovskite photovoltaics $[60,61]$. In Table 1 , a summary of the dependence of $E_{\mathrm{g}}$ and $\mathrm{J}_{\mathrm{sc}}$ on operating temperature for $\mathrm{FTO} / \mathrm{TiO}_{2} / \mathrm{TiO}_{2} / \mathrm{MAPbl}_{3} /$ Spiro-OMeTAD/Au is presented (Extracted from results

Table 1 Dependence of $E_{\mathrm{g}}$ and $J_{\mathrm{sc}}$ on operating temperature for $\mathrm{FTO} / \mathrm{TiO}_{2} / \mathrm{TiO}_{2} / \mathrm{MAPbl}_{3} /$ spiro-OMeTAD/Au. Extracted from results based on Ref. [62]

\begin{tabular}{lll}
\hline $\begin{array}{l}\text { Temperature } \\
\mathrm{K}\end{array}$ & $\begin{array}{l}E_{\mathrm{g}} \\
\mathrm{eV}\end{array}$ & $\begin{array}{l}J_{\mathrm{sc}} \\
\mathrm{mA} \cdot \mathrm{cm}^{-2}\end{array}$ \\
\hline 100 & 1.567 & 15.8 \\
120 & 1.566 & 15.6 \\
140 & 1.566 & 15.1 \\
160 & 1.570 & 15.8 \\
180 & 1.571 & 15.9 \\
200 & 1.575 & 16.1 \\
220 & 1.576 & 16.2 \\
240 & 1.576 & 16.5 \\
260 & 1.579 & 16.7 \\
280 & 1.581 & 16.8 \\
300 & 1.585 & 16.5 \\
320 & 1.587 & 16.6 \\
340 & 1.586 & 17.2 \\
360 & 1.592 & 16.2 \\
\hline
\end{tabular}


based on Ref. [62]). As can be seen in Table 1, with increase in operating temperature, the energy gap increases; $J_{\mathrm{sc}}$ decreases initially and subsequently increases.

In Fig. 6a, b, we investigate the properties of perovskite solar cells based on $\mathrm{MAPbl}_{3}$, from two sources of literature. In the first reference (2015-Zhang), for mesoscopic PSCs $\left(\mathrm{TiO}_{2} / \mathrm{MAPbl}_{3} / \mathrm{Al}_{2} \mathrm{O}_{3} / \mathrm{NiO} /\right.$ carbon) [64], $V_{\text {oc }}$ follows a volcano-like distribution with the maximum value at $\sim 260 \mathrm{~K}$ under constant light intensity and decreases at operating temperatures in the range of $\sim 220-260 \mathrm{~K}$. This decrease is ascribed to charge accumulation near perovskite/electrode interface; the unit cell equilibrium and polarizability are very sensitive to temperature. Normally, $V_{\text {oc }}$ of PSCs have higher value than other candidate cells (e.g., CIGS solar cell and silicon heterojunction solar cell); this is due to the larger $E_{\mathrm{g}}(>1.4 \mathrm{eV})$ of the perovskites. Furthermore, it has been reported that $V_{\text {oc }}$ decreases with decreasing light intensity (from 1 sun to 0.1 sun), which indicates that the permittivity of perovskites plays a critical role in the $V_{\text {oc }}-T$ behavior [64]. $J_{\text {sc }}$ increases with increasing temperature, reaching the maximum value $\left(\sim 22 \mathrm{~mA} \mathrm{~cm}^{-2}\right)$ at around $240 \mathrm{~K}$, which is almost the same for a different PSC structure (FTO/compact $\mathrm{TiO}_{2} /$ porous $\mathrm{TiO}_{2} / \mathrm{MAPbl} 3 /$ Spiro-OMeTAD/Au) [63]. In Fig. 6a, $J_{\text {sc }}$ (for 2017-Wang) has higher value at low temperature (80-200 K) and higher maximum value $\left(\sim 23 \mathrm{~mA} \mathrm{~cm}^{-2}\right)$ (than 2015 -Zhang), which may be due to the better transportation ability of photogenerated holes within the perovskite/NiO interface and electrons within the percolated perovskite/ $/ \mathrm{TiO}_{2}$ networks [64]. In Fig. 6b, the low FF at low temperature $(<250 \mathrm{~K})$ is due to the increased charge carrier diffusion resistance in the $\mathrm{MAPbl}_{3}$ layer. FF increases significantly when the temperature is $>240 \mathrm{~K}$ and its maximum value is attained at $300 \mathrm{~K}$. This increase compensates for the unavoidable decrease in $V_{\text {oc }}$ at elevated temperature (normally, $>260 \mathrm{~K}$ ) (Fig. 6a). As a consequence, PCE increases with increasing temperature (Fig. 6b) and attains a maximum value at $280 \mathrm{~K}$. A decrease in PCE for low temperature (bottom red curve in Fig. 6b) and higher temperature (>300 K in Fig. 6b) may be due to temperature-activated charge transport in
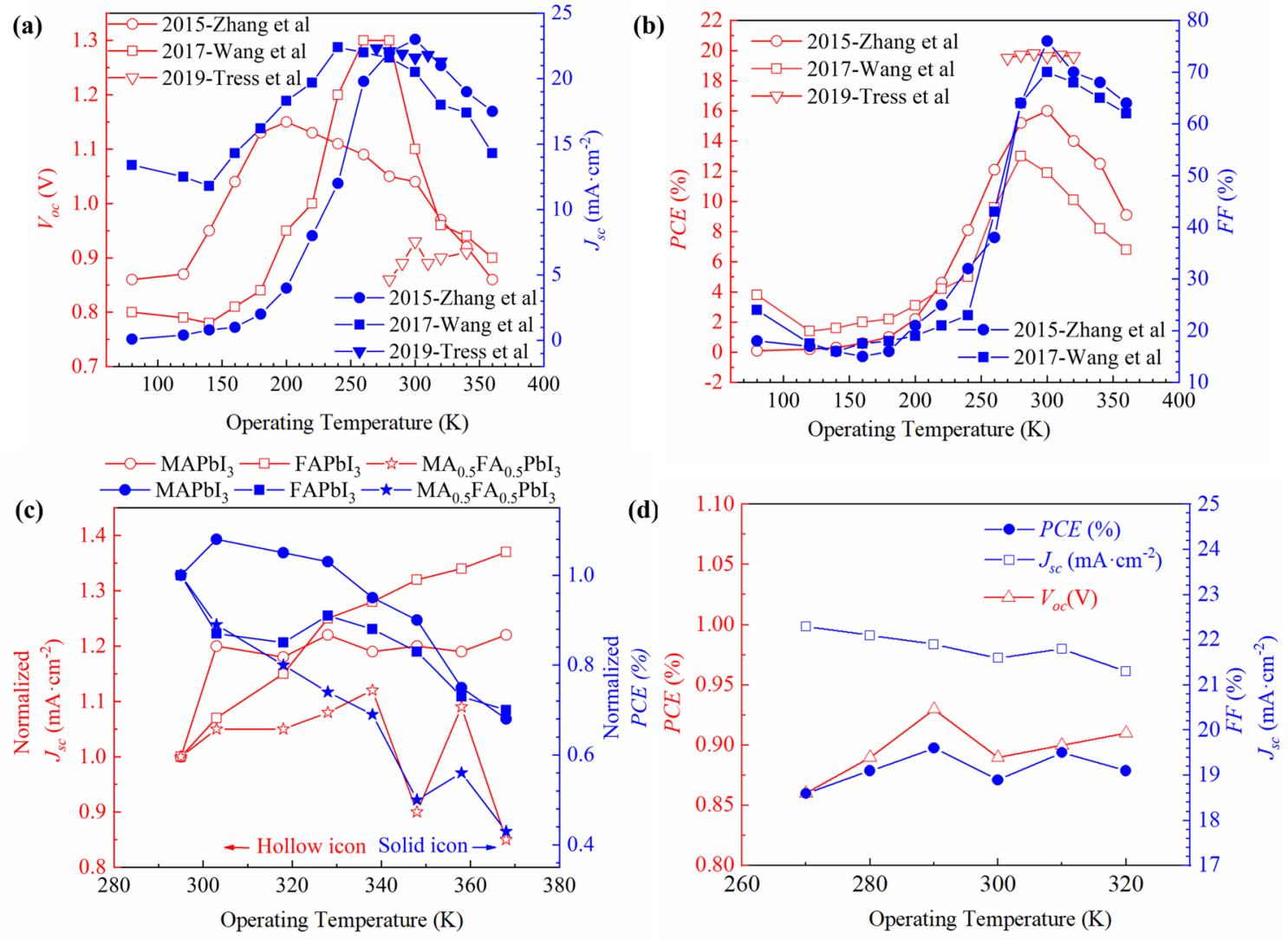

Fig. 6 Temperature dependence of $\mathbf{a}$ PCE and FF and $\mathbf{b} V_{\text {oc }}$ and $J_{\text {sc }}$ of $\mathrm{MAPbl}_{3}$-based PSCs extracted from literature, 2015-Zhang et al., on PSC (FTO/compact $\mathrm{TiO}_{2}$ /porous $\mathrm{TiO}_{2} / \mathrm{MAPbI} / \mathrm{Sp}$ iro-OMeTAD/ $\mathrm{Au})$; and 2017-Wang et al., on PSCs $\left(\mathrm{TiO}_{2} / \mathrm{MAPbl}_{3} / \mathrm{Al}_{2} \mathrm{O}_{3} / \mathrm{NiO} / \mathrm{car}-\right.$ bon) and 2019-Tress et al., on CsMAFAPbl ${ }_{x} \mathrm{Br}_{(1-x)}$-based PSC. c Com-

parison of normalized $J_{\mathrm{sc}}-\mathrm{PCE}-T$ of PSCs based on various perovskite materials. $\mathbf{b}, \mathbf{c}$ Comparison of temperature dependence of PV parameters of MAPbl3, FAPbl3, MAFAPbl 3 and CsMAFAPbl $\mathrm{Br}_{(1-x)}$ $(X=0-1) ; \mathbf{a}, \mathbf{b}$ are extracted from 2015-Zhang (Ref. [63]) and 2017Wang (Ref. [64]) c extracted from Ref. [65] 
charge transport layers (in particular, spiro-OMe-TAD [66]) affecting series resistance and $\mathrm{FF}$, which is similar to other works in the literature $[64,67]$.

The temperature dependence of PV parameters of PSCs ( $\mathrm{FTO} / \mathrm{TiO}_{2}$ compact layer/Mesoporous $\mathrm{TiO}_{2} /$ Perovskite/Au), based on three perovskite materials, $\mathrm{MAPbl}_{3}, \mathrm{FAPbl}_{3}$ and $\mathrm{MAFAPbl}_{3}$, is presented in Fig. 6c (based on data extracted from Ref. [65]. $\mathrm{FAPbl}_{3}$ has an $E_{\mathrm{g}}$ of $1.46 \mathrm{eV}$ which is lower than that of $\mathrm{MAPbl}_{3}\left(E_{\mathrm{g}}\right.$ of $\left.1.57 \mathrm{eV}\right)$ and MAFAPbl ${ }_{3}\left(E_{\mathrm{g}}\right.$ of $1.53 \mathrm{eV})$. The absorption edge, $\lambda_{\mathrm{e}}\left(=1240 / E_{\mathrm{g}} ; E_{\mathrm{g}}\right.$ in $\left.\mathrm{eV}\right)$, of $\mathrm{FAPbl}_{3}$ is $850 \mathrm{~nm}$, showing better performance than $\mathrm{MAPbl}_{3}(790 \mathrm{~nm})$ as a light harvester. The increasing temperature will generally decrease the $E_{\mathrm{g}}$ of a semiconductor material which will eventually lead to a decrease in PCE. The result in Fig. $6 \mathrm{c}$ shows that $J_{\mathrm{sc}}$ increases by $\sim 30 \%$ which may be due to the better stability of $\mathrm{FAPbl}_{3}$ at high temperature ( $>340 \mathrm{~K}$ ). However, this increase is not enough for the compensation of the loss of FF and $V_{\text {oc }}$ values, which eventually results in a low PCE. An interesting phenomenon is that MAFAPbl ${ }_{3}$ shows severe degradation of the PV parameters with increasing temperature. This may be due to the formation of different strain inside the crystalline structure for both $\mathrm{MAPbl}_{3}$ and $\mathrm{FAPbl}_{3}$ due to increasing temperature [65]. The decrease in $V_{\text {oc }}$ with increasing temperature, due to the higher recombination probabilities, results in a decrease in PCE. Besides, the intrinsic carrier concentration depends on $E_{\mathrm{g}}$. The main reason for the decrease in PCE at temperatures $>280 \mathrm{~K}$ is due to the photocurrent hysteresis effect that exists in most of the PSC devices, which has been described in detail in the literature [68]. Although $\mathrm{MAPbl}_{3}, \mathrm{FAPbl}_{3}$ and $\mathrm{MAFAPbl}_{3}$ perovskite solar cells have exhibited high efficiencies, their long-term stability is still a concern for PSCs to be commercialized. The thermal degradation temperature (phase transition temperature) of perovskite materials in PSC are $\sim 328-358 \mathrm{~K}$ for $\mathrm{MAPbl}_{3}$ and $>373 \mathrm{~K}$ for $\mathrm{FAPbl}_{3}$ [69]. The implication is that these perovskite materials have thermal stability problems in working conditions (273-353 K).

Recent studies have shown that, with the addition of inorganic cations (e.g., Cs and/or Rb), the compositions of perovskites can be thermally stable at temperatures $>373 \mathrm{~K}$ [70]. CsMAFAPbl $\mathrm{Br}_{(1-x)}(X=0-1)$-based perovskite solar cell has a wide tunable band gap from 1.4 to $2.3 \mathrm{eV}$ and improved light and moisture stability compared with $\mathrm{FAPbl}_{3}$, which enhances its PCE [71]. Thus, it becomes a matter of design while using hybrid perovskite materials in which the perovskite is combined with various cations and halides. In 2019, Tress et al. [67] investigated the temperature dependence (273-323 K) of $\mathrm{PV}$ parameters with the conditions that were acquired from real-world weather records (Lausanne, Switzerland) and compared their results with silicon heterojunction
(SHJ) cell. In this study, the structure of the PSC is FTO/ perovskite/ $\mathrm{TiO}_{2} /$ Spiro-MeOTAD/Au with $\mathrm{CsFAPb}\left(\mathrm{I}_{0.83} \mathrm{Br}_{0.17}\right)_{3}$ perovskite. The authors reported a monotonous increase in $V_{\text {oc }}$ from $\sim 0.85$ to 0.95 and then decrease to $0.9 \mathrm{~V}$ with increasing temperature, which is similar to the behavior of cells of other perovskite materials (e.g., $\mathrm{MAPbl}_{3}, \mathrm{FAPbl}_{3}$ and $\mathrm{MAFAPbl}_{3}$ ) in the same temperature range, as shown in Fig. 6d. Besides, the change (increasing and decreasing pattern) in PCE can be considered to be almost negligible with slight increase or decrease from 19.5 to $19.8 \%$ and then to $19.6 \%$. Accordingly, we assume that PSCs are less affected by temperature in the range of 300-323 K because of the advantages obtained by adding $\mathrm{Cs}$ ion into MAFAPbl $_{x} \operatorname{Br}_{(1-x)}(X=0-1)$ which effectively avoids the light soaking problem and reduces the recombination traps [72]. Conventional $\mathrm{MAPbl}_{3}$ and $\mathrm{FAPbl}_{3}$ perovskites can be improved by the addition of multiple cations; the different size of the cations compensates the MAPbI3-type perovskites to lead to new multi-cation perovskites that have several advantages. It has been shown that RbCsMAFAPbl PSCs exhibit low degradation (5\%) in PCE after subjecting the device at $85^{\circ} \mathrm{C}$ under continuous illumination $(500 \mathrm{~h})$ with full intensity at maximum power point (MPP) [52]. As a consequence, with the addition of inorganic cation (e.g., $\mathrm{Cs}$ and $\mathrm{Rb}$ ) into MAFAPbl ${ }_{3}$ perovskite, the suppression of halide segregation and wide and tunable band gaps that are beneficial and suitable not only for perovskite solar cells, but also with significant compositional properties for tandem solar cells (e.g., perovskite/CIGS and perovskite/ silicon) has been demonstrated [52].

Most of the investigations of the temperature dependence of PV parameters in PSCs focus on perovskites based on single cation $\left(\mathrm{MAPbl}_{3}\right.$ or $\left.\mathrm{FAPbl}_{3}\right)$ and double cation (MAFAPbl ${ }_{3}$ ), which show a relative stable performance around room temperature with a significant decrease in performance at both high and low temperatures. Marko Jost et al. [73] report a low-power temperature coefficient of $-0.17 \% \mathrm{~K}^{-1}$ under the outdoor condition testing, which also shows that perovskite solar cells (FAMAPbl ${ }_{3}$ ) are highly thermally stable under increasing temperature at a range between 25 and $85^{\circ} \mathrm{C}$. In addition to temperature-dependent measurements, the aging test of temperature cycle for the module has been studied recently. In the study by Cheacharoen et al. [74], almost no degradation of PCE has been observed when the solar cells are encapsulated and cycled between 243 and $358 \mathrm{~K}$ in dark experimental conditions. Domanski et al. [75] have shown that CsMAFAPbl ${ }_{3}$-based PSC exhibits lower degradation rate during the temperature cycle (from 263 to $338 \mathrm{~K}$ ). In this experiment, the PSC module was stressed with the device held continuously at $338 \mathrm{~K}$; degradation was observed in the Hole Transport Material (HTM). Furthermore, Jonas A. Schwenzer et al. [76] compared the 
degradation of PCE and other PV parameters between $\mathrm{MAPbl}_{3}, \mathrm{MAFAPbl}_{3}$ and triple cation (CsMAFAPbl ${ }_{3}$ ). The results show that $\mathrm{Cs} \mathrm{MAFAPbl}_{3}$ has low degradation and maintains high PCE for long running time with a cycling temperature test (from room temperature to high temperature of $333 \mathrm{~K}$ and then back to room temperature). $\mathrm{Cs}_{0.05}\left(\mathrm{MA}_{0.17} \mathrm{FA}_{0.83}\right)_{0.95} \mathrm{~Pb}\left(\mathrm{I}_{0.83} \mathrm{Br}_{0.17}\right)_{3}$, with $\left.E_{\mathrm{g}}=1.62 \mathrm{eV} 20\right]$, has been demonstrated as one of the perovskite materials with high thermal stability for the fabrication of PSCs. Moreover, by combining this perovskite as the top solar cell with CIGS solar cell processed on flexible substrate as the bottom solar cell, PCE of $25 \%$ has been shown for the solar cell module [77].

\section{Conclusion}

The temperature dependence of PV parameters of CIGS and perovskite solar cells is investigated, as function of operating temperature and substrate temperature. $T_{\text {sub }}$ at $823 \mathrm{~K}$ is critical for CIGS on SLG substrates, where Na incorporates into the CIGS absorber and lowers the resistivity. SS substrates can sustain $T_{\text {sub }}$ as high as SLG substrate; however, the diffusion of the detrimental impurities (e.g., $\mathrm{Fe}$ ) increases with increasing temperature; this is a major challenge for high PCE CIGS modules on Fe containing SS substrates. Increased grain boundary density and defects contribute to large resistivity when $T_{\text {sub }}$ is low.

In general, the PCE of PSC showed slight temperature dependence, in contrast to CIGS solar cells. The operating temperature dependency of both perovskite and CIGS solar cells is initially due to the effect of $V_{\text {oc }}$ on temperature. The variation in $V_{\text {oc }}$ is mainly from the defect concentration which can be attributed to high recombination rate with increasing temperature. For most perovskite solar cells, $J_{s c}$ in general, increases with increasing temperature from lower temperature to around $\sim 250-280 \mathrm{~K}$. For future development, this work provides useful information for the design and understanding of stable, high-efficiency thin-film solar cells which have the potential for working in terrestrial and space applications.

The comparison of substrate temperature and operating temperature, based on different substrates of CIGS solar cells, provides the knowledge of advantages and disadvantages that are associated with using each substrate material. The development of perovskite material has the trend to couple the alkaline cations (e.g., Cs and $\mathrm{Rb}$ ) to improve the thermal stability. The side-by-side discussion provides the insight into which composition of the perovskite material has the most thermal tolerance with better PV performance parameters and the effect of temperature on different substrates for CIGS solar cells. This study is useful to determine/identify the best possible combination of perovskite/CIGS tandem solar cell that has high PCE for real-world working conditions. Besides, in real-world applications, the thermal testing procedures are critical for assessing the life expectancy of the device; thus, this temperature dependence study provides results for each perovskite and CIGS solar cell on different substrates.

Author contributions Equal.

Data availability Not applicable.

\section{Compliance with ethical standards}

Conflicts of interest The authors declare no conflicts of interest.

Code availability Not applicable.

Ethical approval Not applicable.

\section{References}

1. Fraunhofer Institute for Solar Energy Systems. PHOTOVOLTAICS REPORT. Fraunhofer www.ise.fraunhofer.de. Accessed 17 June 2020

2. Theelen M, Daume F (2016) Stability of Cu (In, Ga) Se2 solar cells: a literature review. Solar Energy 133:586-627. https://doi. org/10.1016/j.solener.2016.04.010

3. Lee TD, Ebong AU (2017) A review of thin film solar cell technologies and challenges. Renew Sustain Energy Rev 70:1286-1297. https://doi.org/10.1016/j.rser.2016.12.028

4. Singh P, Ravindra NM (2012) Temperature dependence of solar cell performance - an analysis. Solar Energy Mater Solar Cells 101:36-45. https://doi.org/10.1016/j.solmat.2012.02.019

5. Wysocki JJ, Rappaport P (1960) Effect of temperature on photovoltaic solar energy conversion. J Appl Phys 31(3):571-578. https ://doi.org/10.1063/1.1735630

6. Varshni YP (1967) Temperature dependence of the energy gap in semiconductors. Physica 34(1):149-154. https://doi. org/10.1016/0031-8914(67)90062-6

7. Devaney WE, Mickelsen RA (1988) Vacuum deposition processes for CulnSe2 and CulnGaSe2 based solar cells. Solar Cells 24(1):19-26. https://doi.org/10.1016/0379-6787(88)90032-4

8. Kato T, Wu JL, Hirai Y, Sugimoto H, Bermudez V (2018) Record Efficiency for thin-film polycrystalline solar cells up to $22.9 \%$ achieved by $\mathrm{Cs}$-Treated $\mathrm{Cu}(\mathrm{In}, \mathrm{Ga})(\mathrm{Se}, \mathrm{S}) 2$. IEEE J Photovolt 9(1):325-330. https://doi.org/10.1109/JPHOTOV.2018.2882206

9. Ball JM, Lee MM, Hey A, Snaith HJ (2013) Low-temperature processed meso-superstructured to thin-film perovskite solar cells. Energy Environ Sci 6(6):1739-1743. https://doi.org/10.1039/ c3ee40810h

10. Green M, Ho-Baillie A, Snaith $H$ (2014) The emergence of perovskite solar cells. Nat Photonics 8:15-20. https://doi.org/10.1038/ NPHOTON.2014.134

11. Kojima A, Teshima K, Shirai Y, Miyasaka T (2009) Organometal halide perovskites as visible-light sensitizers for photovoltaic cells. J Am Chem Soc 131(17):6050-6051. https://doi. org/10.1021/ja809598r

12. Yang WS et al (2017) lodide management in formamidiniumlead-halide-based perovskite layers for efficient solar cells. 
Science 356(6345):1376-1379. https://doi.org/10.1126/scien ce.aan2301

13. Jošt $M$ et al (2019) 21.6\%-efficient monolithic perovskite/ $\mathrm{Cu}(\mathrm{In}, \mathrm{Ga}) \mathrm{Se} 2$ tandem solar cells with thin conformal hole transport layers for integration on rough bottom cell surfaces. ACS Energy Lett 4(2):583-590. https://doi.org/10.1021/acsen ergylett.9b00135

14. Brenner TM, Egger DA, Kronik L, Hodes G, Cahen D (2016) Hybrid organic-inorganic perovskites: low-cost semiconductors with intriguing charge-transport properties. Nat Rev Mater 1(1):15007. https://doi.org/10.1038/natrevmats.2015.7

15. Palmstrom AF et al (2019) Enabling flexible all-perovskite tandem solar cells. Joule 3(9):2193-2204. https://doi. org/10.1016/j.joule.2019.05.009

16. Carron R et al (2018) Refractive indices of layers and optical simulations of $\mathrm{Cu}(\mathrm{In}, \mathrm{Ga}) \mathrm{Se} 2$ solar cells. Sci Technol Adv Mater 19(1):396-410. https://doi.org/10.1080/14686996.2018.14585 79

17. Singh $P$, Singh $S N$, Lal $M$, Husain $M$ (2008) Temperature dependence of I-V characteristics and performance parameters of silicon solar cell. Solar Energy Mater Solar Cells 92(12):1611-1616. https://doi.org/10.1016/j.solma t.2008.07.010

18. Liu S, Simburger E, Matsumoto J, Garcia A, Ross J, Nocerino J (2005) Evaluation of thin-film solar cell temperature coefficients for space applications. Prog Photovol Res Appl 13:149-156. https://doi.org/10.1002/pip.602

19. Leijtens T, Bush KA, Prasanna R, McGehee MD (2018) Opportunities and challenges for tandem solar cells using metal halide perovskite semiconductors. Nat Energy 3(10):828-838. https:// doi.org/10.1038/s41560-018-0190-4

20. Lang $\mathrm{F}$ et al (2020) Proton radiation hardness of perovskite tandem photovoltaics. Joule 4(5):1054-1069. https://doi. org/10.1016/j.joule.2020.03.006

21. Ramanujam J, Singh UP (2017) Copper indium gallium selenide based solar cells-a review. Energy Environ Sci 10(6):1306-1319. https://doi.org/10.1039/c7ee00826k

22. Fan JCC (1986) Theoretical temperature dependence of solar cell parameters. Solar Cells 17(2):309-315. https://doi. org/10.1016/0379-6787(86)90020-7

23. Ong KH et al (2018) Review on substrate and molybdenum back contact in CIGS thin film solar cell. Int J Photoenergy 2018:9106269. https://doi.org/10.1155/2018/9106269

24. Li W, Yan X, Aberle AG, Venkataraj S (2017) Effect of a TiN alkali diffusion barrier layer on the physical properties of Mo back electrodes for CIGS solar cell applications. Curr Appl Phys 17(12):1747-1753. https://doi.org/10.1016/j.cap.2017.08.021

25. Marlein J, Khelifi S, Burgelman M, Belghachi A (2008) Electrical characteristics of $\mathrm{Cu}(\mathrm{In}, \mathrm{Ga}) \mathrm{Se} 2$ thin films solar cells on metallic foil substrates. Mater Sci 10:15-20. https://doi. org/10.4229/23rdeupvsec2008-3do.5.6

26. Szalaj A, Keane J, Tuttle JR (2000) Conference record of the 28th IEEE photovoltaic specialists conference. Anchorage, AK, USA., Sept 2000, p 1042

27. Chirilă A et al (2013) Potassium-induced surface modification of $\mathrm{Cu}(\mathrm{In}, \mathrm{Ga})$ Se 2 thin films for high-efficiency solar cells. Nat Mater 12(12):1107-1111. https://doi.org/10.1038/nmat3789

28. Wuerz R et al (2009) CIGS thin-film solar cells on steel substrates. Thin Solid Films 517(7):2415-2418. https://doi.org/10.1016/j. tsf.2008.11.016

29. Kim K et al (2020) Mechanisms of extrinsic alkali incorporation in CIGS solar cells on flexible polyimide elucidated by nanoscale and quantitative analyses. Nano Energy 67:104201. https://doi. org/10.1016/j.nanoen.2019.104201

30. Khelifi $S$ et al (2010) Characterization of flexible thin film CIGSe solar cells grown on different metallic foil substrates.
Energy Procedia 2(1):109-117. https://doi.org/10.1016/j.egypr o.2010.07.017

31. Liang $X$ et al (2016) Substrate temperature optimization for $\mathrm{Cu}(\mathrm{In}, \mathrm{Ga}) \mathrm{Se} 2$ solar cells on flexible stainless steels. Appl Surf Sci 368:464-469. https://doi.org/10.1016/j.apsusc.2016.02.003

32. Zortea $\mathrm{L}$ et al (2018) $\mathrm{Cu}(\mathrm{In}, \mathrm{Ga}) \mathrm{Se} 2$ solar cells on low cost mild steel substrates. Sol Energy 175:25-30. https://doi.org/10.1016/j. solener.2017.12.057

33. Bae D, Kwon S, Oh J, Kim WK, Park H (2013) Investigation of $\mathrm{Al} 2 \mathrm{O} 3$ diffusion barrier layer fabricated by atomic layer deposition for flexible $\mathrm{Cu}(\mathrm{In}, \mathrm{Ga}) \mathrm{Se} 2$ solar cells. Renew Energy 55:6268. https://doi.org/10.1016/j.renene.2012.12.024

34. Eisenbarth T, Caballero R, Kaufmann CA, Eicke A, Unold T (2012) Influence of iron on defect concentrations and device performance for $\mathrm{Cu}(\mathrm{In}, \mathrm{Ga}) \mathrm{Se} 2$ solar cells on stainless steel substrates. Prog Photovolt Res Appl 20(5):568-574. https://doi.org/10.1002/ pip. 2260

35. Chen Z et al (2019) Single-crystal MAPbl3 perovskite solar cells exceeding 21\% power conversion efficiency. ACS Energy Lett 4(6):1258-1259. https://doi.org/10.1021/acsenergylett.9b00847

36. Zhang $Y$ et al (2020) Achieving reproducible and high-efficiency (>21\%) perovskite solar cells with a presynthesized FAPbl3 powder. ACS Energy Lett 5(2):360-366. https://doi.org/10.1021/ acsenergylett.9b02348

37. Theelen $M$ et al (2017) Determination of the temperature dependency of the electrical parameters of CIGS solar cells. J Renew Sustain Energy 9(2):021205. https://doi. org/10.1063/1.4979963

38. Daoudia AK, El Hassouani Y, Benami A (2016) Investigation of the effect of thickness, band gap and temperature on the efficiency of CIGS solar cells through SCAPS-1D. Int J Eng Tech Res 6:71

39. Hu C, White RM (1983) Solar cells. McGraw-Hill, New York, p 21

40. Nell ME, Barnett AM (1987) The spectral p-n junction model for tandem solar-cell design. IEEE Trans Electron Devices 34(2):257266. https://doi.org/10.1109/T-ED.1987.22916

41. Dimmler B, Powalla M, Schaeffler R (2005) CIS solar modules: pilot production at Wuerth Solar, pp 189-194

42. Zhang L, Liu F-f, Li F-y, He Q, Li B-z, Li C-j (2012) Structural, optical and electrical properties of low-temperature deposition $\mathrm{Cu}(\operatorname{InxGa} 1$ - x)Se2 thin films. Sol Energy Mater Sol Cells 99:356361. https://doi.org/10.1016/j.solmat.2012.01.002

43. Reinhard P et al (2013) Review of progress toward $20 \%$ efficiency flexible CIGS solar cells and manufacturing issues of solar modules. IEEE J Photovolt 3(1):572-580

44. Zhang L, He Q, Jiang W-L, Liu F-F, Li C-J, Sun Y (2009) Effects of substrate temperature on the structural and electrical properties of $\mathrm{Cu}(\mathrm{In}, \mathrm{Ga}) \mathrm{Se} 2$ thin films. Sol Energy Mater Sol Cells 93(1):114-118. https://doi.org/10.1016/j.solmat.2008.09.002

45. Kodigala SR (2010) Chapter 8-Cu(In1-xGax)Se2 and Culn(Se1 - xSx) 2 thin film solar cells. In: Kodigala SR (ed) Thin films and nanostructures, vol 35. Academic Press, New York, pp 505-679

46. Lammer M, Klemm U, Powalla M (2001) Sodium co-evaporation for low temperature $\mathrm{Cu}(\mathrm{In}, \mathrm{Ga}) \mathrm{Se} 2$ deposition. Thin Solid Films 387(1):33-36. https://doi.org/10.1016/S0040-6090(00)01712-0

47. Wang $\mathrm{H}$ et al (2010) Effect of substrate temperature on the structural and electrical properties of CIGS films based on the onestage co-evaporation process. Semicond Sci Technol 25:055007. https://doi.org/10.1088/0268-1242/25/5/055007

48. Yang ZY, Wang LD, Song RX, Zhang DX, Fei WD (2015) Effects of substrate temperature on the properties of $\mathrm{Cu}(\mathrm{In}, \mathrm{Ga}) \mathrm{Se} 2$ thin films prepared by sputtering from a quaternary target. Adv Mater Res 1061-1062:209-214. https://doi.org/10.4028/www. scientific.net/AMR.1061-1062.209

49. Chirilă A et al (2011) Cu(In, Ga)Se2 solar cell grown on flexible polymer substrate with efficiency exceeding $17 \%$. Prog Photovolt Res Appl 19(5):560-564. https://doi.org/10.1002/pip.1077 
50. Zhang W et al (2017) Cu(In, Ga)Se2 thin film solar cells grown at low temperatures. Solid-State Electronics 132:57-63. https:// doi.org/10.1016/j.sse.2017.03.003

51. Gloeckler M, Sites JR, Metzger WK (2005) Grain-boundary recombination in $\mathrm{Cu}(\mathrm{In}, \mathrm{Ga}) \mathrm{Se} 2$ solar cells. J Appl Phys 98(11):113704. https://doi.org/10.1063/1.2133906

52. Saliba M et al (2016) Incorporation of rubidium cations into perovskite solar cells improves photovoltaic performance. Science 354(6309):206. https://doi.org/10.1126/science.aah5557

53. Saliba $M$ et al (2016) A molecularly engineered hole-transporting material for efficient perovskite solar cells. Nat Energy 1(2):15017. https://doi.org/10.1038/nenergy.2015.17

54. Saliba $\mathrm{M}$ et al (2016) Cesium-containing triple cation perovskite solar cells: improved stability, reproducibility and high efficiency. Energy Environ Sci 9(6):1989-1997. https://doi. org/10.1039/c5ee03874j

55. Leguy AM et al (2015) Reversible hydration of $\mathrm{CH} 3 \mathrm{NH} 3 \mathrm{Pbl} 3$ in films, single crystals, and solar cells. Chem. Mater. 27(9):33973407. https://doi.org/10.1021/acs.chemmater.5b00660

56. Cuce E, Cuce PM, Bali T (2013) An experimental analysis of illumination intensity and temperature dependency of photovoltaic cell parameters. Appl Energy 111:374-382. https://doi. org/10.1016/j.apenergy.2013.05.025

57. Shockley W, Queisser HJ (1961) Detailed balance limit of efficiency of $\mathrm{p}-\mathrm{n}$ junction solar cells. J Appl Phys 32(3):510-519. https://doi.org/10.1063/1.1736034

58. Eperon GE, Stranks SD, Menelaou C, Johnston MB, Herz LM, Snaith HJ (2014) Formamidinium lead trihalide: a broadly tunable perovskite for efficient planar heterojunction solar cells. Energy Environ Sci 7(3):982-988. https://doi.org/10.1039/c3ee4 $3822 \mathrm{~h}$

59. Lv S et al (2014) One-step, solution-processed formamidinium lead trihalide (FAPbl $(3-\mathrm{x}) \mathrm{Cl}$ ) for mesoscopic perovskite-polymer solar cells. Phys Chem Chem Phys 16(36):19206-19211. https://doi.org/10.1039/c4cp02113d

60. Shao Y et al (2016) Grain boundary dominated ion migration in polycrystalline organic-inorganic halide perovskite films. Energy Environ Sci 9(5):1752-1759. https://doi.org/10.1039/ c6ee00413j

61. Zou Y, Holmes RJ (2016) Temperature-dependent bias poling and hysteresis in planar organo-metal halide perovskite photovoltaic cells. Adv Energy Mater 6(7):1501994. https://doi. org/10.1002/aenm.201501994

62. Leong WL et al (2016) Identifying fundamental limitations in halide perovskite solar cells. Adv Mater 28(12):2439-2445. https ://doi.org/10.1002/adma.201505480

63. Zhang H, Qiao X, Shen Y, Wang M (2015) Effect of temperature on the efficiency of organometallic perovskite solar cells. J Energy Chem 24(6):729-735. https://doi.org/10.1016/j.jeche m.2015.10.007

64. Wang M, Yim W-L, Liao P, Shen Y (2017) Temperature dependent characteristics of perovskite solar cells. ChemistrySelect 2(16):4469-4477. https://doi.org/10.1002/slct.201700776
65. Aharon S, Dymshits A, Rotem A, Etgar L (2015) Temperature dependence of hole conductor free formamidinium lead iodide perovskite based solar cells. J Mater Chem A 3(17):9171-9178. https://doi.org/10.1039/c4ta05149a

66. Dualeh A, Moehl T, Nazeeruddin MK, Grätzel M (2013) Temperature dependence of transport properties of spiro-MeOTAD as a hole transport material in solid-state dye-sensitized solar cells. ACS Nano 7(3):2292-2301. https://doi.org/10.1021/nn4005473

67. Tress W et al (2019) Performance of perovskite solar cells under simulated temperature-illumination real-world operating conditions. Nat Energy 4(7):568-574. https://doi.org/10.1038/s4156 0-019-0400-8

68. Chen HW, Sakai N, Ikegami M, Miyasaka T (2015) Emergence of hysteresis and transient ferroelectric response in organo-lead halide perovskite solar cells. J Phys Chem Lett 6(1):164-169. https://doi.org/10.1021/jz502429u

69. Conings B et al (2015) Intrinsic thermal instability of methylammonium lead trihalide perovskite. Adv Energy Mater 5(15):1500477. https://doi.org/10.1002/aenm.201500477

70. Lee JW, Kim SG, Yang JM, Yang Y, Park NG (2019) Verification and mitigation of ion migration in perovskite solar cells. APL Mater 7(4):041111. https://doi.org/10.1063/1.5085643

71. Lee JW, Kim DH, Kim HS, Seo SW, Cho SM, Park NG (2015) Formamidinium and cesium hybridization for photo-and moisturestable perovskite solar cell. Adv Energy Mater 5(20):1501310. https://doi.org/10.1002/aenm.201501310

72. Wali Q, Elumalai NK, Iqbal Y, Uddin A, Jose R (2018) Tandem perovskite solar cells. Renew Sustain Energy Rev 84:89-110. https ://doi.org/10.1016/j.rser.2018.01.005

73. Jošt M (2020) Perovskite solar cells go outdoors: field testing and temperature effects on energy yield. Adv Energy Mater. https:// doi.org/10.1002/aenm.202000454

74. Cheacharoen R, Rolston N, Harwood D, Bush KA, Dauskardt RH, McGehee MD (2018) Design and understanding of encapsulated perovskite solar cells to withstand temperature cycling. Energy Environ Sci 11(1):144-150. https://doi.org/10.1039/c7ee02564e

75. Domanski K, Alharbi EA, Hagfeldt A, Grätzel M, Tress W (2018) Systematic investigation of the impact of operation conditions on the degradation behaviour of perovskite solar cells. Nat Energy 3(1):61-67. https://doi.org/10.1038/s41560-017-0060-5

76. Schwenzer JA et al (2018) Temperature variation-induced performance decline of perovskite solar cells. ACS Appl Mater Interfaces 10(19):16390-16399. https://doi.org/10.1021/acsam i.8b01033

77. McMeekin DP et al (2016) A mixed-cation lead mixed-halide perovskite absorber for tandem solar cells. Science 351(6269):151. https://doi.org/10.1126/science.aad5845

Publisher's Note Springer Nature remains neutral with regard to jurisdictional claims in published maps and institutional affiliations. 